\title{
INVESTIGATION OF WATER QUALITY AND GROUNDWATER FLOW IN A KARST WATERSHED IN BLANCO COUNTY, TEXAS
}

\author{
Robert Salinas \\ Center for Water Research, Department of Geological Sciences, University of Texas at San Antonio, One UTSA \\ Circle, San Antonio, Texas, 78249,USA, Robert.Salinas@my.utsa.edu \\ Yongli Gao \\ Center for Water Research, Department of Geological Sciences, University of Texas at San Antonio, One UTSA \\ Circle, San Antonio, Texas, 78249, USA,yongli.gao@utsa.edu
}

Lijun Tian

Center for Water Research, Department of Geological Sciences, University of Texas at San Antonio, One UTSA Circle, San Antonio, Texas, 78249, USA,Lijun.Tian@utsa.edu

Yunxia Li

College of Resources and Environmental Science, Hunan Normal University, Changsha, Hunan, China 410081, liyx@hunnu.edu.cn

\section{Scott Gardner}

C.L. Browning Ranch, 159 Browning Drive, Johnson City, Texas, 78636, USA, clbrowningranch@gmail.com

\begin{abstract}
In any natural system, environmental and geomorphic responses are more extreme and frequent when caused or affected by human activities. Karst aquifers differ from other aquifer types in that they are composed of complex matrix, fracture, and conduit porosities. As valuable resources for societies and ecosystems, karst aquifers are highly vulnerable to pollution and must be well studied for proper protection.
\end{abstract}

This study combines ongoing monitoring data with hydrochemistry data from sampling sites within the Honeycut Hollow Creek Watershed, Blanco County, Texas. Flow measurements revealed that the discharge of Honeycut Creek Spring does not respond to local precipitation. The wettest September in 2018 in recorded history in southcentral Texas resulted in minimum discharge, which is one order of magnitude lower than the discharge recorded from April 2017. During low flow conditions, the salinity of spring water is higher with elevated levels of nitrate and higher concentrations of other ions, especially sulfate.

There has been little variation for water isotopes of Honeycut Creek Spring during 2017-2019, which may demonstrate relatively long residence time of groundwater and a deep flow path. This could also explain why the discharge of Honeycut Spring does not respond to lo- cal precipitation. The deuterium excess values of these spring water samples are close to $10 \%$, which may indicate little evaporation during precipitation and groundwater movement.

These investigations aim to reveal the relationship between water quality of springs and local geoenvironmental conditions, evaluate the impact of long-term climate variations and wet and dry conditions on water quality, identify possible sources of nitrate among sampling sites, and ultimately generate a baseline model for a better understanding on how the karst aquifer responds to recharge events and potential contamination.

\section{Introduction}

The Pedernales River contributes $23 \%$ of the annual inflow to Lake Travis, which supplies the city of Austin and many municipalities along the Colorado River as the sole source of drinking water (Wierman et al., 2017). Coupled with reports projecting a population growth in Travis County from 1 million in 2010 to 1.6 million by 2050 and Austin as the fastest growing city in the United States from 2011 to 2016 (U.S. Census Bureau, 2019), the importance of understanding limited water recourses is paramount to sustainable management. As such, understanding the watersheds that contribute to the Pedernales River Basin is also of importance. Honeycut Hollow Creek is a 1,240 -acre watershed draining from the 
south to the north directly into the Pedernales River. The river and small streams play critical roles in the ecology of the area as well. The central Texas ecosystem has 81 plant and 67 animal species rated "very rare" or "critically imperiled". The ecosystem is ranked in the top ten nationwide for bird and reptile diversity. Of the 29 different plant communities two are found nowhere else (Powell et al., 2018). Additionally, Central Texas is an important North American stopover for migratory birds (Shackelford, 2005).

Within this watershed rests the 977-acre C.L. Browning Ranch (Figure 1). While initially a cattle and sheep ranch, as well as scattered orchards, it was converted in 2001 to a research ranch to be operated as a model of land stewardship and environmental preservation practices. All livestock grazing and agricultural growth have been ceased. Studies at CL Browning Ranch have been combining ongoing monitoring data (precipitation, water temperature, spring discharge, and specific conductance) with hydrochemistry data $(\mathrm{pH}$, water isotopes, anions, cations, and trace metals) of four sampling sites including a spring, creek, and two tributaries within the Honeycut Hollow Creek watershed. The objectives of these studies are to (1) investigate the water quality of groundwater and surface water; (2) evaluate the impact of longterm climate variations and extreme weather conditions on water quality; (3) identify possible sources of nitrate among the four sampling sites. The ultimate goal of this research is to create a baseline model for a better understanding of how the aquifer responds to recharge events and potential contamination.

\section{Hydrologic Setting}

The Browning Ranch lies within a locality with several features of importance bearing the name "Honeycut", which is in part due to an 1836 land grant to James Roland Hunnicutt. The misnomer "Honeycut" is due to misspellings on subsequent surveys (Knott and Chusid, 2003). This title has been given to the formation, creek, and spring that reside within the ranch. These creeks in the ranch serve a drainage basin locally known as the 1,240-acre Honeycut Hollow watershed, which is part of the larger Pedernales River Basin.

Eleven springs are found in the C.L. Browning Ranch. Honeycut Spring is the largest and has never been known to run dry, even during periods of drought. Additionally, Honeycut Spring discharges from a lower formation than

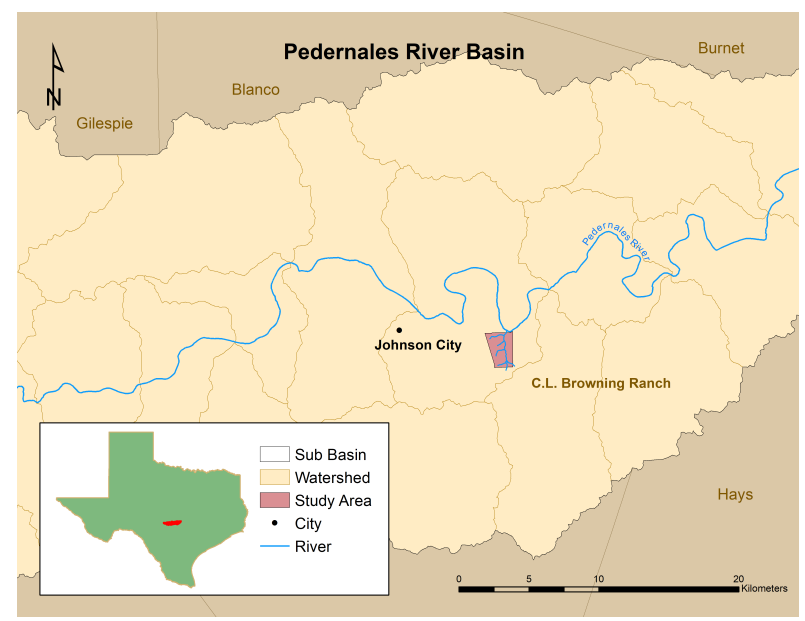

Figure 1. Map of the Pedernales River Basin within the Texas Hill Country. The Browning Ranch, southwest of Johnson City, rests within the Honeycut Hollow Creek watershed just south of the Pedernales River.

other springs in the ranch, residing in the Cow Creek Limestone. Honeycut Creek flows across the Honeycut Spring Location, running south to north, which traverses through the Glen Rose Limestone, Hensell Sand, and Cow Creek Limestone formations. Four ephemeral creeks feed the Honeycut Creek: Turkey Creek, Red Tail Creek, Rock Creek, and Walnut Creek.

The Glen Rose Limestone caps the elevated area of the ranch, with a six-to-nine-foot layer of Hensell Sand Formation underneath. The Honeycut Creek flows through the ranch, creating a subtle valley that cuts through the Hensell Sand Formation to expose the Cow Creek Limestone to the north. The Glen Rose Limestone, Hensell Sand Formation, and Cow Creek Limestone all fall within the Trinity Aquifer (Barnes, 1986). This erosion continues into the Marble Falls Limestone of the Marble Falls Aquifer, exposing a small confining bed of Mississippian and Devonian rocks, and finally into the Honeycut Formation. This final formation lies within the karstic Ellenburger - San Saba aquifer (TWDB 1990a and 1990b) (Figure 2).

The local formations yield very small to moderate quantities of fresh to slightly saline wells in most of the county, while the Honeycut Formation's presence of dolomite may contribute to higher levels of magnesium. Larger saline yields within the Glen Rose Limestone may be from the massive basal limestone, which contains solution channels carrying large quantities of water (Follett, 1974). Within the Trinity Aquifer region, the Hensell 


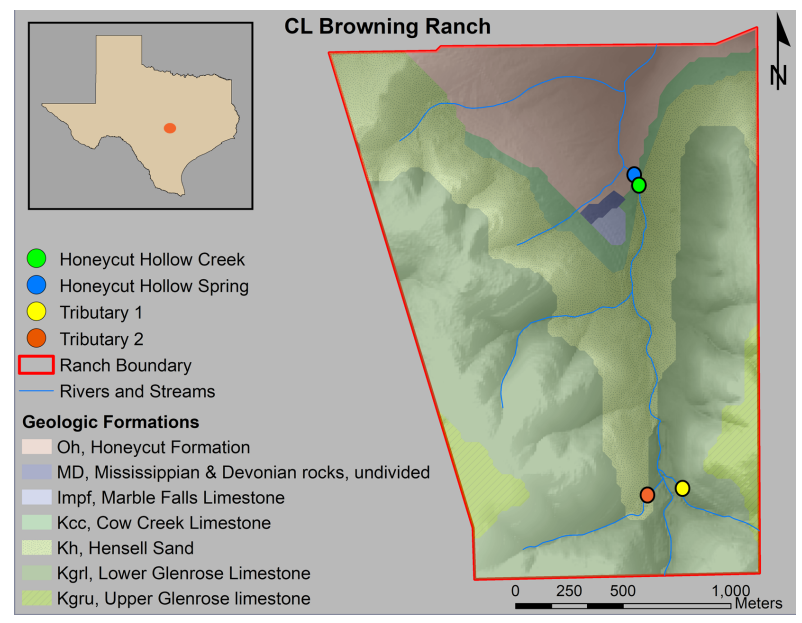

Figure 2. C.L. Browning Ranch and the prominent formations within its boundaries including four sampling sites. In addition to the sites at the Honeycut Creek (green) and Honeycut Spring (blue), there are two tributary sampling sites: Tributary 1 (yellow) within Turkey Creek and Tributary 2 (red) within Rock Creek.

Sand is comprised of weakly cemented clay, quartz, and calcareous sand (Inden, 1974).

The broad upland area to the south contributes and directs flow from the Glen Rose, underlain by the Hensell, downward and laterally towards the Honeycut Creek and finally into the Pedernales River. This recharge would include rainwater infiltration along the Turkey, Red Tail, Rock, and Walnut creeks with a small amount of water infiltrating through the soil, subsoil, and bedrock of the uplands.

\section{Geochemistry and Isotope Data}

Groundwater flows through geological materials when moving from recharge to discharge areas. Along this flow path, dissolution, precipitation, and ion-exchange processes occur. Ionic concentrations depend on the composition of the precipitation, geological structure and mineralogy of aquifer formations and contact time with aquifer host rocks (Andre et al., 2005). As such, hydrogeochemical compositions of groundwater can be useful in understanding the origin and history of groundwater flow.

Water isotope values (Figure 3) are nearly constant, with no response to precipitation. This is most likely due to long underground residence times while mixing within established reservoirs. The deuterium excess values of the spring and creek water samples are close to $10 \%$, which may indicate little evaporation during precipitation and groundwater movement.
The Piper diagram is an effective graphic representation of water chemistry to display dissolved constituents in water. Relative concentrations of anions and cations for these water samples are shown in the Piper diagram (Figure 4). For cations, the dominant ions are $\mathrm{Ca}^{2+}$ and $\mathrm{Mg}^{2+}$. While for anions, the dominant ion is $\mathrm{HCO}_{3}^{-}$. However, there is a trend towards $\mathrm{SO}_{4}^{2-}$ during heavy precipitation events (Figure 4).

\section{Discussion}

Major ions were measured for the Honeycut Spring, the Honeycut Creek in the upstream of the spring, and the two tributaries further upstream from the spring. The ions include fluoride, chloride, nitrite, bromide, nitrate, phosphate, sulfate, lithium, sodium, ammonium, potassium, magnesium, calcium, strontium, and barium. With no recent livestock or agriculture use, contaminant levels are expected to be low, with trace constituents linked most likely to vegetation recovery and abundance of wildlife in the ranch or from geological formations. Within each sampling site, major ions were compared at individual levels in comparison to water quality standards.

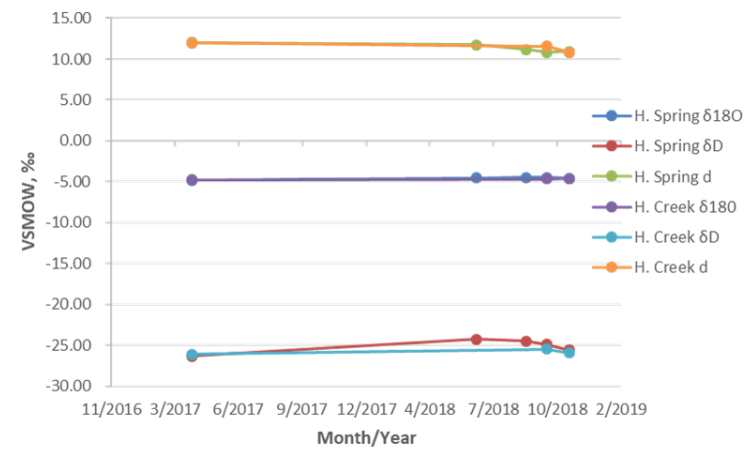

Figure 3. Isotope values for four sampling sites spanning March 2017 to October 2019.

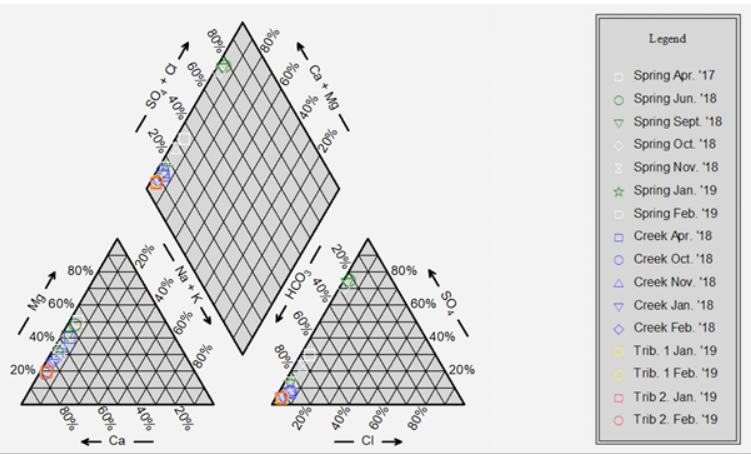

Figure 4. Piper diagram for the four sampling sites; April 2017 to February 2019. 
Utilizing water quality regulations all tested ions were compared against maximum contaminant level goal (MCLG), maximum contaminant level (MCL), and secondary maximum contaminant levels (SMCL). While fluoride, chloride, and nitrate were all present within the sampling sites, levels did not meet or surpass water quality regulations (Table 1 ).

Peak level of sulfate within the Honeycut Spring were present from June 2018 to October 2018, with a maximum of $436.68 \mathrm{mg} / \mathrm{L}$, which is over the SMCL of $250 \mathrm{mg} / \mathrm{L}$. While this time does correspond with high precipitation, sulfate concentrations did not rise significantly during other comparable precipitation events. A single peak level of barium was observed at Honeycut Spring in March 2019, with all other sampling times showing non-detectable barium levels. Water quality regulations enforce MCLG of $2 \mathrm{mg} / \mathrm{L}$ for barium in drinking water. SMCL total dissolved solid (TDS) of $500 \mathrm{mg} / \mathrm{L}$ is recommended for drinking water. Two samples from the Honeycut Spring during April 2017, $523 \mathrm{mg} / \mathrm{L}$, and September 2018, $707 \mathrm{mg} / \mathrm{L}$ surpasses the SMCL. These high TDS levels occurred during a month of low and high precipitation, respectively (Table 2).

Calcium and Magnesium are dominant cations in most groundwater and contribute to water "hardness" (Gurdak et al., 2002). Nitrate and sulfate follow closely to TDS levels across all sampling sites (Figure 5).

\section{Precipitation and Discharge Levels}

TDS responds to precipitation events, with some lag time. The discharge of Honeycut Spring reached its minimum level in September 2018, corresponding to the

\begin{tabular}{|c|c|c|c|c|c|c|}
\hline \multicolumn{2}{|c|}{ lons (mg/L) } & Fluoride & Chloride & Nitrite & Nitrate & Sulfate \\
\hline \multirow{4}{*}{ Average } & Spring & 2.26 & 9.50 & na & 1.01 & 131.65 \\
\hline & Creek & 1.62 & 8.16 & na & 1.17 & 12.40 \\
\hline & Tributary 1 & 1.45 & 8.12 & na & 1.61 & 10.83 \\
\hline & Tributary 2 & 1.51 & 7.38 & na & 2.29 & 12.17 \\
\hline \multirow{4}{*}{ MAX } & Spring & 2.90 & 12.00 & na & 2.04 & 436.68 \\
\hline & Creek & 1.79 & 8.70 & na & 2.45 & 14.10 \\
\hline & Tributary 1 & 1.55 & 9.38 & na & 2.61 & 11.60 \\
\hline & Tributary 2 & 1.62 & 7.89 & na & 2.49 & 12.23 \\
\hline \multirow{4}{*}{ MIN } & Spring & 1.73 & 8.29 & na & 0.00 & 32.23 \\
\hline & Creek & 1.37 & 7.73 & na & 0.00 & 9.73 \\
\hline & Tributary 1 & 1.34 & 7.07 & na & 0.00 & 9.71 \\
\hline & Tributary 2 & 1.38 & 6.97 & na & 2.18 & 12.10 \\
\hline \multicolumn{2}{|c|}{$\begin{array}{c}\text { Water Quality } \\
\text { Regulations }\end{array}$} & 4 (MCLG) & $\begin{array}{c}250 \\
\text { (Secondary MCL) }\end{array}$ & $\begin{array}{c}1 \\
\text { (MCLG) }\end{array}$ & $\begin{array}{c}10 \\
\text { (MCLG) }\end{array}$ & $\begin{array}{c}250 \\
\text { (Secondary MCL) }\end{array}$ \\
\hline
\end{tabular}

Table 1. Average, maximum, and minimum observed levels of fluoride, chloride, nitrite, nitrate, and sulfate of the four sampling sites against national primary drinking water regulations (U.S. EPA, 2009). Concentrations below the detection limit are listed "na".

\begin{tabular}{|c|c|c|c|c|c|}
\hline \multicolumn{2}{|c|}{ lons (mg/L) } & Barium & Calcium & Magnesium & TDS \\
\hline \multirow{4}{*}{ Average } & Spring & 0.36 & 88.46 & 36.75 & 488.43 \\
\hline & Creek & na & 70.41 & 18.64 & 366.70 \\
\hline & Tributary 1 & na & 70.88 & 16.65 & 358.83 \\
\hline & Tributary 2 & na & 86.08 & 15.48 & 364.00 \\
\hline \multirow{4}{*}{ MAX } & Spring & 3.16 & 153.71 & 61.29 & 707.00 \\
\hline & Creek & na & 104.49 & 21.41 & 414.00 \\
\hline & Tributary 1 & na & 98.26 & 21.68 & 367.00 \\
\hline & Tributary 2 & na & 96.64 & 15.94 & 371.00 \\
\hline \multirow{4}{*}{ MIN } & Spring & na & 44.53 & 26.79 & 377.00 \\
\hline & Creek & na & 41.89 & 14.11 & 336.00 \\
\hline & Tributary 1 & na & 34.15 & 14.20 & 341.00 \\
\hline & Tributary 2 & na & 66.35 & 15.06 & 358.00 \\
\hline \multicolumn{2}{|c|}{$\begin{array}{c}\text { Water Quality } \\
\text { Regulations }\end{array}$} & $\begin{array}{c}2 \\
\text { (MCLG) }\end{array}$ & & & $\begin{array}{c}500 \\
\text { (Secondary MCL) }\end{array}$ \\
\hline
\end{tabular}

Table 2. Average, maximum, and minimum observed levels of barium, calcium, magnesium, and TDS against national primary drinking water regulations (U.S. EPA, 2009). Concentrations below the detection limit are listed "na".

maximum of TDS - $707 \mathrm{mg} / \mathrm{L}$. However, During May 2019, a month of high precipitation, TDS levels did not rise significantly until August 2019 during a monthly of low precipitation low (Figure 6).

Discharge does not have a fast response to precipitation, though a long period of "lag" could be present for Honeycut Creek.

Peaks of discharge are present during low levels of precipitation, and periods of greatest magnitude between discharge and precipitation are not consistent (Figure 7).

\section{Conclusions}

Honeycut Hollow Creek and tributaries are $\mathrm{Ca}-\mathrm{Mg}$ $\mathrm{HCO}_{3}^{-}$types, while the Honeycut Hollow Spring is $\mathrm{Ca}-\mathrm{Mg}-\mathrm{HCO}_{3}{ }^{-}$type and shifts to $\mathrm{Ca}-\mathrm{Mg}-\mathrm{SO}_{4}{ }^{2-}$ type in response to increased precipitation. This shift may be caused by the dissolution of gypsum layers in the lower Glen Rose formation. Water isotope values are nearly constant with no response to precipitation due to long underground residence time while mixing within established reservoirs.

The discharges of Honeycut Hollow Creek and Honeycut Hollow Spring do not respond to local precipitation. Minimal flow was observed during the wettest periods of the year. Spring sulfate levels increased after intense precipitation events which are likely caused by interaction with gypsum beds or gypsiferous limestone. 


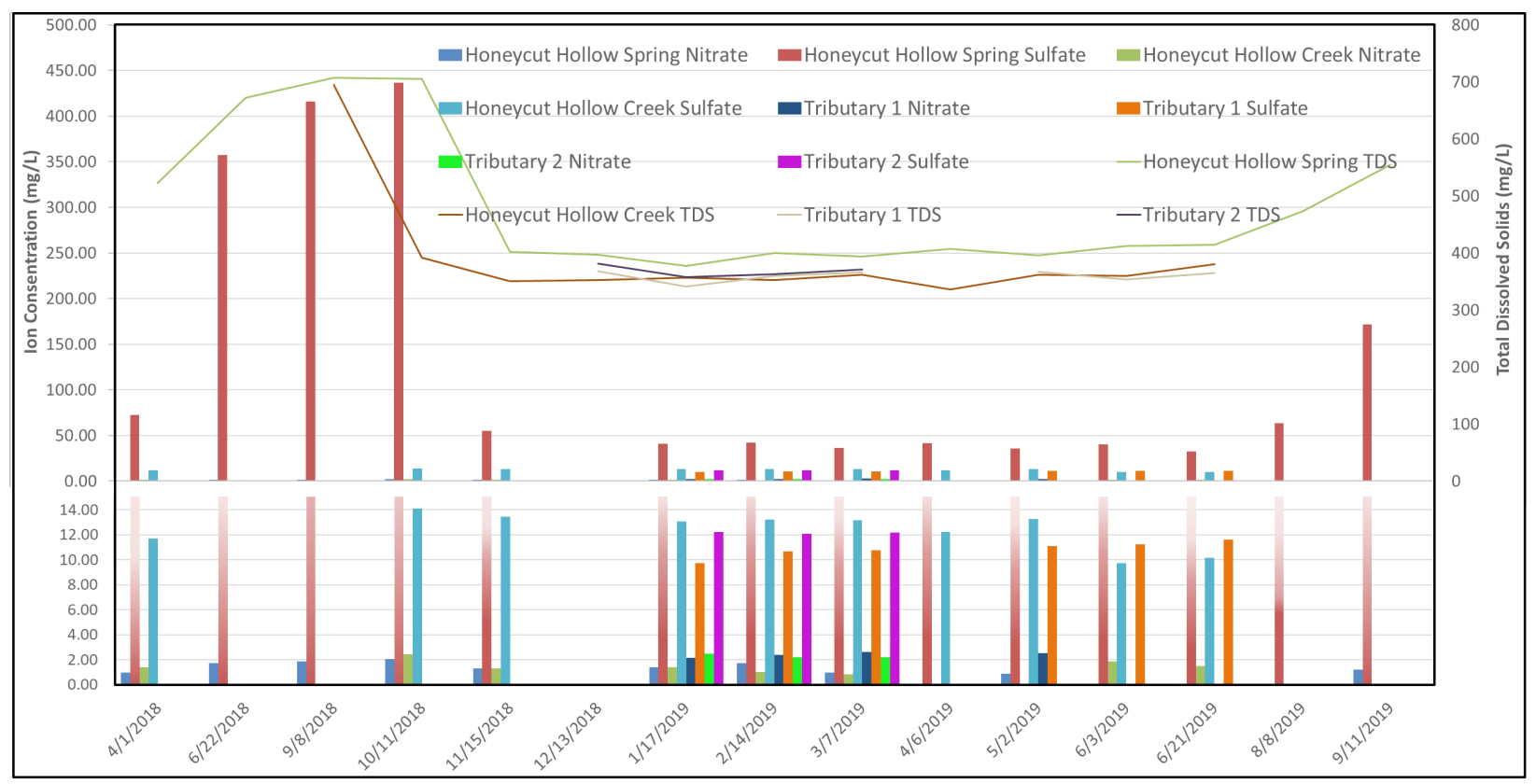

Figure 5. Concentrations of nitrate and sulfate of sampling sites in comparison to TDS from April 2018 to September 2019.

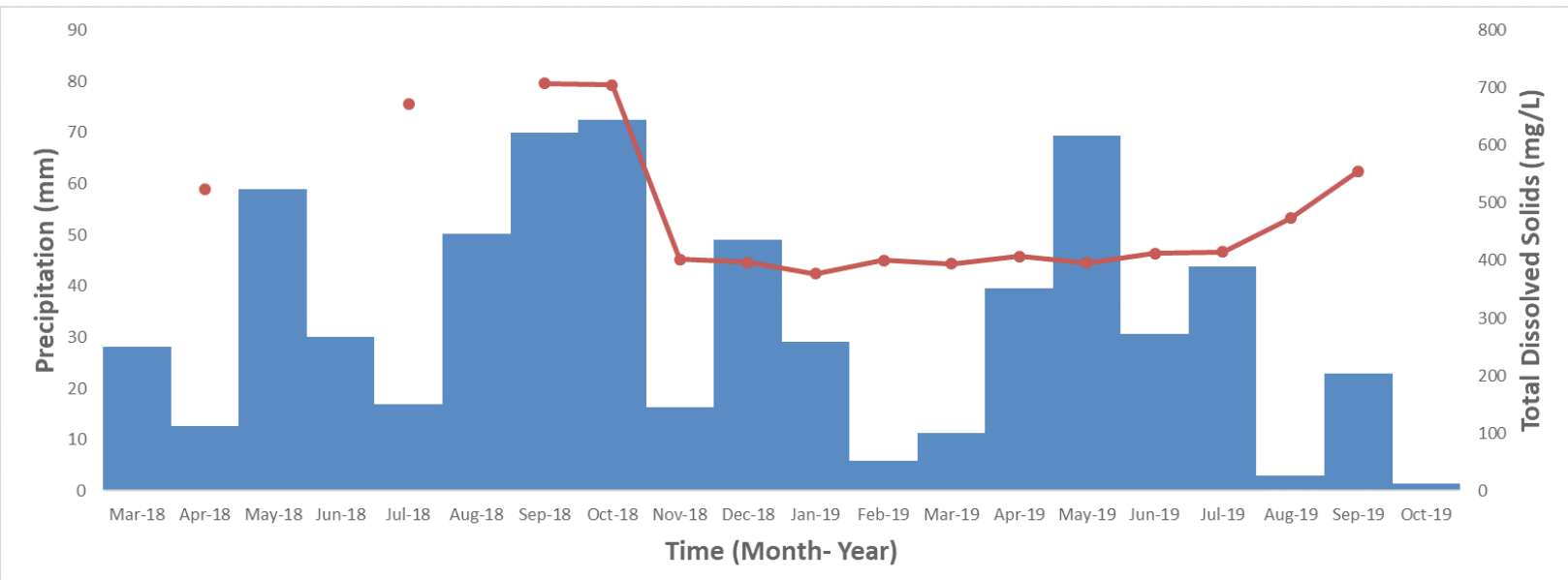

Figure 6. Precipitation levels (blue) against TDS for Honeycut Spring (red line) over the period of March 2018 to October 2019.

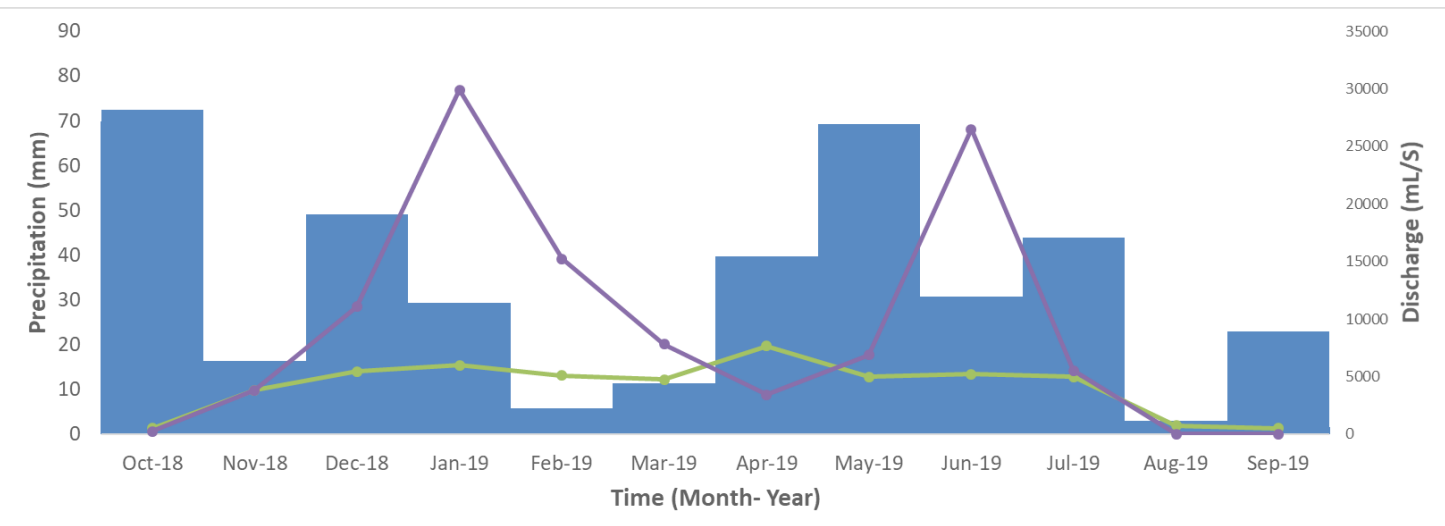

Figure 7. Precipitation levels (blue) against discharge of Honeycut Spring (green) and Honeycut Creek (purple) over the period of October 2018 to September 2019. 


\section{References}

Andre L, Franceschi M, Pouchan P, Atteia O. 2005. Using geochemical data and modelling to enhance the understanding of groundwater flow in a regional deep aquifer, Aquitaine Basin, south west of France. Journal of Hydrology 305: 40-62.

Barnes VE. 1986. Geologic Atlas of Texas, Llano Sheet. Bureau of Economic Geology, The University of Texas at Austin.

Follett CR. August 1974. Ground-Water Resources of Blanco County, Texas. Texas Water Development Board, Report 174.

Gurdak J, Spahr N, Greve A. 2002. Geological Survey, Gunnison, \& National Water-Quality Assessment Program. (2002). Water-quality data analysis of the upper Gunnison River watershed, Colorado, 1989-99.

Inden RF. 1974. Lithofacies and depositional model for a Trinity Cretaceous sequence, central Texas, in B.F. Perkins, ed., Aspects of Trinity Geology:

Geoscience and Man, v. 8, p. 37-52.

Knott L, Chusid J. 2003. Cultural landscape report for the Browning Ranch Blanco County, Texas. Austin, TX.

Powell AM, Worthington RD, Powell SA. 2018. Flowering plants of Trans-Pecos Texas and adjacent areas: a book to promote botanical and environmental education, scientific exploration and conservation in Trans-Pecos and adjacent areas. Fort Worth, TX: BRIT Press.

Shackelford CE, Rozenburg ER, Hunter WC, Lockwood MW. 2005. Migration and the Migratory Birds of Texas: Who They Are and Where They Are Going. Texas Parks and Wildlife PWD BK W7000-511 (11/05). Booklet, 34pp.

Texas Water Development Board (TWDB). 1990a. Major Aquifers of Texas. Map.

Texas Water Development Board (TWDB). 1990b. Minor Aquifers of Texas. Map.

U.S. Census Bureau. Community Facts. [updated 2009 October 12; cited 2019] Available from: http:// factfinder.census.gov.
U.S. EPA. National Primary Drinking Water Regulations. [updated 2009 May; cited 2019 Nov] Available from: https://www.epa.gov/ ground-water-and-drinking-water/nationalprimary-drinking-water-regulations.

Wierman DA, Walker J, Fiesler R, Watson J, Broun A, Haddad S, Schauer J. 2017. How Much Water is in the Pedernales? Determining the source of Base Flow to the Pedernales River in Northern Blanco, Hays, and Travis Counties. The Meadows Center for Water and the Environmental. September 2017. 4 p. 